\title{
Clinical and Molecular Genetic Findings of Cerebral Arteriopathy with Subcortical Infarcts and Leukoencephalopathy
}

\author{
Subkortikal Enfarktüslü Serebral Arteriyopati ve Lökoensefalopati Olgularının Klinik ve \\ Moleküler Genetik Bulguları
}

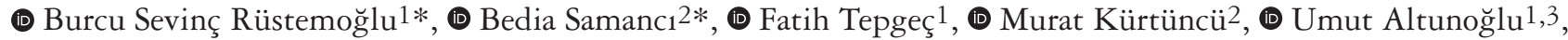

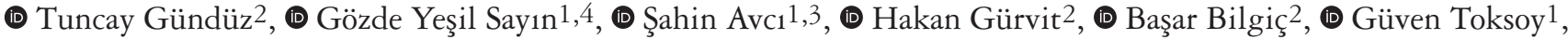
(1) Mefkure Eraksoy ${ }^{2}$, (1) Haşmet Hanağası ${ }^{2}$, (1) Zehra Oya Uyguner ${ }^{1 * *}$

${ }^{1}$ Istanbul University, Istanbul Faculty of Medicine, Department of Medical Genetics, Istanbul, Turkey 2Istanbul University, Istanbul Faculty of Medicine, Department of Neurology, Istanbul, Turkey ${ }^{3}$ Koc University School of Medicine, Department of Medical Genetics, Istanbul, Turkey ${ }^{4}$ Bezmialem Vakif University Faculty of Medicine, Department of Medical Genetics, Istanbul, Turkey

${ }^{*}$ Equal contribution

${ }^{* *}$ Corresponding Author

\begin{abstract}
Objective: Most lacunar strokes are sporadic, and hypertension, diabetes, smoking, and cardiovascular diseases are among its main risk factors. Strokes caused by small vessel diseases are generally associated with single-gene disorders with familial dominant and recessive inheritance. The most common condition is cerebral autosomal dominant arteriopathy, with subcortical infarcts and leukoencephalopathy (CADASIL), associated with the NOTCH3 gene. An infrequent form of this disease is the cerebral autosomal recessive arteriopathy with subcortical infarcts and leukoencephalopathy (CARASIL), revealed with pathogenic HTRA1 gene variants related to distinct molecular pathways. The neurological and cranial magnetic resonance imaging (MRI) findings are very similar to CADASIL; however, earlier than expected onset of common alopecia in man, low back pain, and more severe memory impairment are the differences in terms of clinical presentations. Clinical findings of 22 patients from 16 families with widespread white matter lesions in the periventricular field in the brain were investigated with molecular genetic findings.

Materials and Methods: Clinical examination results and cranial MRI findings are reported, and NOTCH3 and HTRA1 genes are sequenced stepwise by Sanger and next-generation sequencing techniques.

Results: Missense changes in epidermal growth factor (EGF)-like domain in the NOTCH3 are found in 18 cases from 14 families. Two different homozygous pathogenic missense and non-sense variants, in the HTRA1 gene, were detected in four patients from two families. The disease onset age was approximately 16 years earlier in cases carrying pathogenic variants located in the encoding region of EGF-like domains 1-6 of NOTCH3.

Conclusion: In the NOTCH3 gene with c.382T >C (p.C128R), c.555T > G (p.C185W), and c.1903C > T (p.R635C) and in the HTRA1 gene c.235C > T (p.Q79*) are presented for the first time in this study. Molecular genetic investigation of CADASIL and CARASIL is important to support the clinical diagnosis, determine the inheritance model, provide patient and family counseling, manage disease process, and evaluate possible treatment strategies.

Keywords: CARASIL, CADASIL, autosomal dominant, recessive, NOTCH3, HTRA1

$\ddot{O} z$

Amaç: Laküner inmelerin çoğu sporadik olup, hipertansiyon, diyabet, sigara ve kardiyovasküler hastalıklar önemli risk faktörleri arasındadır. Küçük damar hastalıklarının yol açtığı inmeler ise genel olarak ailevi özellik taşıyan dominant ve resesif kalıtım modelleriyle gözlenen tek gen hastalıklarıyla ilişkilidir. En yaygın bilineni NOTCH3 genindeki patojenik varyantlarla ortaya çıkan subkortikal enfarkt ve lökoensefalopati ile giden otozomal dominant serebral arteriyopati (CADASIL) hastalığıdır. Bu hastalı̆̆ın çok daha nadir bir kliniği ise patojenik HTRA1 gen değişimleri ile gözlenen resesif (CARASIL) formudur. Nörolojik ve kraniyal manyetik rezonans görüntüleme (MRG) bulguları CADASIL'e çok benzer olan CARASIL, moleküler patolojik yolakların farklı olması, hafıza disfonksiyonunun daha ağır seyretmesi, özellikle erkeklerde beklenenden daha erken yaşta başlayan yaygın alopesi görülmesi, bă̆ dokusunun etkilenmesi ve
\end{abstract}

Address for Correspondence/Yazışma Adresi: Oya Zehra Uyguner Prof. PhD, Istanbul University, Istanbul Faculty of Medicine, Department of Medical Genetics, Istanbul, Turkey

Phone: +90 2124142000 (32327) E-mail: o.uyguner@istanbul.edu.tr ORCID: orcid.org/0000-0002-2035-4338

Received / Geliş Tarihi: 08.12.2020 Accepted / Kabul Tarihi: 17.05.2021

${ }^{\circ}$ Copyright 2021 by Turkish Neurological Society

Turkish Journal of Neurology published by Galenos Publishing House. 
hastaların önemli bir oranında bel ağrısı yakınmaları gibi özellikleri temelinde CADASIL'den farklı bir klinik seyir izler. Bu çalışmada beyinde periventriküler alanda yaygın ak madde lezyonlarının gözlendiği 16 aileden 22 olgunun klinik bulguları moleküler genetik bulguları eşliğinde araştırıldı.

Gereç ve Yöntem: Olguların klinik muayene sonuçları ile kraniyal MRG bulguları raporlandı, NOTCH3 ve HTRA1 genleri kademeli olarak Sanger ve yeni nesil dizi yöntemleriyle incelendi.

Bulgular: On dört aileden 18 olguda NOTCH3 geninde epidermal büyüme faktörü (EGF)-like domain bölgesinde sistein dozunu değiştiren heterozigot yanlış anlamlı değişimler ve iki aileden dört hastada HTRA1 geninde, biri anlamsız diğeri yanlış anlamlı tipte iki farklı homozigot patojenik varyant saptandı. NOTCH3'ün 1-6 EGF-like domain yapısını kodlayan bölgede patojenik varyant taşıyan olgularda hastalık bulgularının yaklaşık 16 yıl daha erken başladığı gözlendi.

Sonuç: NOTCH3 geninde tespit edilen c.382T >C (p.C128R), c.555T>G (p.C185 W), c.1903C > T (p.R635C) ile HTRA1 geninde saptanan c.235C > T (p.Q79*) ilk kez bu çalışmada gösterildi. CADASIL ve CARASIL olgularında moleküler genetik tanı, klinik tanıyı desteklemek, kalıtım modelini belirlemek, hasta ve ailelerine danışmanlık hizmeti sunmak, hastalık sürecini yönetmek ve olası tedavi stratejilerini değerlendirmek için önemlidir.

Anahtar Kelimeler: CARASIL, CADASIL, otozomal dominant, resesif, NOTCH3, HTRA1

\section{Introduction}

Cerebral autosomal dominant and recessive arteriopathy with subcortical infarcts and leukoencephalopathy (CADASIL, MIM\# 125310 and CARASIL, MIM\# 600142, respectively) are small vessel diseases of genetic origin that are different from cerebral amyloid angiopathy (1). CADASIL, which is the most common hereditary disease causing stroke and vascular dementia, begins at the age of 30-60 years, characterized by multiple subcortical ischemic lesions and lacunar infarcts, and reported as "familial subcortical dementia", "hereditary multiple infarct dementia", and "chronic familial vascular encephalopathy" in previous years. It was named under the acronym CADASIL, considering the common findings in patients (2). CADASIL was mapped to 19p13.12 in the genome in genetic linkage analysis studies conducted by various groups in 1993-1996, and missense pathogenic variants in the NOTCH3 gene constituted the genetic basis of the disease (3). The NOTCH3 gene, which consists of 33 coding exons, encodes a 2321 $\mathrm{kb}$ transmembrane receptor protein involved in the evolutionarily conserved Notch signaling pathway (4). With rare exceptions, the molecular pathology causing CADASIL is associated with disruption of the tertiary structure of the receptor as a result of an increased or decreased number of cysteines in the epidermal growth factor (EGF)-like domain chain of the NOTCH3 peptide, and pathogenic variants are intensely associated with the gene's exon regions 2-4, 6-12, 16-19, 21, and 22, and rarely in gene's intron regions $-7,-15,-17$, and -23 (5). Prevalence studies of the disease were generally conducted in small populations, and it was reported as 2-4: 100,000 in Finland and 4.6: 100,000 in Western Scotland $(6,7)$. The genome records of 60,706 unrelated individuals examined in ExAC, one of the open-source databases, revealed the frequency of the total change of cysteine transformations on the EGF-like domain of NOTCH3 as 3.4: 1000 (8), suggesting that some cysteine-related changes progress with a very mild clinical picture that does not require medical assistance. CARASIL, which is similar to CADASIL in terms of vasculopathy, is a different disease characterized by alopecia, spondylosis, progressive motor dysfunction, and more severe and typically accompanying dementia and reported less frequently in populations. A linkage analysis study in five different families revealed that the gene responsible for the disease was $H T R A 1$, which encodes the HtrA serine peptidase 1 enzyme located at 10q26.13 (9). Protease activity may decrease upon the loss of function of this enzyme and further, the transforming growth factor- $\beta$ (TGF-b) signaling pathway, important in regulating proliferation, differentiation, survival, and apoptosis of many cells and glioma cells, will remain unsuppressed. Immunohistochemical analysis of affected patients revealed an increased amount of TGF-b1 in the thickened tunica intima in the cerebral small arteries. In conclusion, the biological basis of the disease was explained as the inhibition of TGF-b signal suppression $(9,10)$. As an autosomal recessive disease, whereby carriers are expected as asymptomatic, heterozygous pathogenic HTRA1 gene variant carriers in some individuals show CADASIL-like findings without early-onset alopecia and spondylosis suggested that dominantly inherited forms of the disease (MIM\# 616779) may also exist $(11,12)$.

In this study, clinical and molecular genetic findings of 22 patients from 16 families diagnosed with atherosclerotic and nonhypertensive cerebral small vessel disease were presented.

\section{Materials and Methods}

\section{Patient group}

Our study group consisted of 22 patients from 16 families, who were followed up with CADASIL/CARASIL clinical diagnosis based on clinical and neuroimaging findings in Istanbul University, Istanbul Faculty of Medicine, Neurology Clinic, and were referred to the Department of Medical Genetics for molecular genetic diagnosis and genetic counseling. Detailed demographic characteristics of patients and systemic complaints and findings (head-neck, cardiovascular system, musculoskeletal system, genitourinary system, skin, and hair findings) were noted. Detailed neurological history of each patient was taken and examination was performed. Except for two patients with unreachable cranial magnetic resonance imaging (MRI), all patients were evaluated in terms of periventricular white matter disorders, temporal white matter disorders, lacunar infarcts, and microhemorrhages. Genetic clinical examinations of patients were performed, and extended family trees were drawn. The study was approved by the Ethics Committee of Istanbul University, Istanbul Faculty of Medicine (date: 17.12.2015, no: 398480). Peripheral blood samples of $2 \mathrm{ml}$ were taken into $\mathrm{K}_{3}$ EDTA tubes for deoxyribonucleic acid isolation from the participants who signed the consent to the study.

\section{Molecular Genetic Testing}

Molecular genetic analysis was carried out in three stages. In the first step, exons $2-6$ and $11^{\text {th }}$ regions of the $\mathrm{NOTCH}_{3}$ 
(NM_000435.3) gene were sequenced by the Sanger method (ABI3500). Patient samples without associated pathogenic variants were analyzed for the whole NOTCH3 gene by nextgeneration sequencing technology within the scope of panel gene (Ion Torrent PGM platform). Pathogenic variants detected in this study were confirmed by the Sanger sequencing. Patients without associated nucleotide changes in the $\mathrm{NOTCH} 3$ gene were analyzed with Sanger sequencing to scan the nine exons of the HTRA1 (NM_002775.5) gene and its exon-intron border regions $( \pm 20 \mathrm{bp})$. Sanger sequencing was performed only for regions with pathogenic variants in affected siblings of index patients.

\section{Bioinformatics Analyzes}

Electropherograms in Sanger sequencing were analyzed with SeqScape Manager Analysis Program v3. The sequence alignment using compression method and mapping files of the panel-gene sequence analysis in Torrent Server was transferred to Ion Reporter, wherein the browser extensible data (BED) (with the annotated data of nucleotides) file was loaded. The hotspot and variant data were previously processed in the BED file. Then, analyzed within the framework of the Ion Reporter analysis flow chart. Ensembl Genome Browser was used for gene sequence information (13). The dbSNP ClinVar (14) and the Human Mutation Data Bank (HGMD) were used for previously known pathogenic variants information (15).

\section{Statistical Analysis}

The demographic and clinical characteristics of the cohort were examined with the independent samples t-test for continuous variables and the chi-square test for categorical variables. Categorical variables were presented as numbers and percentages. Continuous variables were presented as mean and standard deviation. Data were statistically analyzed with the Statistical Package for the Social Sciences software package.

\section{Results}

\section{Clinical and Radiological Findings}

The mean age of participants was $52 \pm 11.3$ years, wherein 8 were female and 14 were male. The mean age of complaint onset was $40.3 \pm 13.17$ years, mean age at presentation was $45.9 \pm 11.43$ years, except for three patients (patient-3, -14, and -19), without complaints, who were included in the study since they were siblings of index patients. Parents of one of the index patients (patient-22) were from the same settlement. Complaints at admission: Only forgetfulness in 5 patients (patient-5, -11, -12, -13, and -17); only headache in 5 patients (patient-21 had migraine with aura, patient-7 had migraine without aura, patient- $4,-9$, and -15 had tension-type headache); paresthesia in 2 patients (patient-1 and -22); weakness in 2 patients (patient-10 and -16); dysarthria in 1 patient (patient-2); difficulty in walking in 1 patient (patient-20); gait difficulties and tension-type headache in 1 patient (patient-6); gait difficulties, tension-type headache, and blurred vision in 1 patient (patient-8); and forgetfulness and tension-type headache in 1 patient (patient-18). Acute/chronic ischemic stroke was found in 11 patients (patient-2, $-4,-6,-10,-11,-12,-13,-14,-15,-16$, and -21$)$, recurrent stroke in 2 patients (patient-2 and -16), and microhemorrhage in 1 patient (patient-8). Apart from patients who presented with the complaint of forgetfulness, three patients had cognitive impairment history (patient-6, -7, and -8) and one had single epileptic seizure history (patient-4). Complaints of six patients were accompanied by urinary incontinence (patient-5, -6, -9, -11, -12, and -21). The medical history revealed that six patients had hypertension (patient-7, -8 , -9, -10, -11, and -12). A psychiatric evaluation revealed that four patients had a depressive mood history (patient-5, -7, -8, -9), one had atypical psychosis (patient-17), and one had a panic disorder history (patient-10). One patient had low back pain (patient-5) and one had alopecia (patient-20), whereas scoliosis and varicose were not found. The cranial MRI findings of 20 patients are shown in Table 1 .

\section{Molecular Findings}

Twelve different $\mathrm{NOTCH}_{3}$ variants were found in 14 of the index patients and two different HTRA1 gene variants were found in two other index patients, all to be compatible with the inheritance models (Table 1). All variants in the NOTCH3 gene were missense or non-synonymous changes in the EGF-like domain or link peptides of these domains, leading to cysteine gain or loss. The distribution of variants in the NOTCH3 gene according to index patients revealed five in exon 4 , one in exon 5 , four in exon 11, and one in exons 12, 19, and 22 (Figure 1). Two different variants, one non-sense, and the other missense were detected in the HTRA1 gene.

\section{Discussion}

Stroke and vascular dementia associated with cerebral small vessel diseases is an increasingly important health problem in populations with an increasing average age. Publications from Turkey contributed to the national and international literature with the clinical and genetic findings of CADASIL; however, to the best of our knowledge, publications on CARASIL are unavailable $(17,18,19,20,21,22,23,24,25)$. Autosomal recessive disease rates are expected to be higher in closed populations with a high rate of consanguineous marriages compared to Western populations, and the average rate of consanguineous marriages in Turkey is $21.3 \%$, according to the Turkish Statistical Institute (25). Therefore, the frequency of CARASIL in our country may be higher than in Western populations, and patients without associated variants in the NOTCH3 gene should be candidates for HTRA1 gene screening.

A study of the genetic and clinical findings of 752 patients with CADASIL evaluated from 224 different literature sources (26) revealed that the disease occurred with stroke in $52 \%$ of patients, cognitive impairment in $46 \%$, migraine in $23 \%$, and psychiatric disease in $24 \%$, mainly depressive mood and the mean age of symptom onset was 43 years. The neuroimaging reported that $72 \%$ of patients had leukoencephalopathy and $4 \%$ had epileptic seizures. In addition, the review reported that 18 different variants were shown in exon $3,4,6,10,11,19$, and 22 regions of the $\mathrm{NOTCH} 3$ gene were the most frequently detected CADASIL mutations worldwide, and all increased and decreased the number of cysteines in the EGF-like domain region. A study from Turkey of 25 patients with CADASIL with a pathogenic variant in the NOTCH3 gene revealed that the mean age of disease onset was 38.8 years, and $28 \%$ of the group had psychiatric disorders, $52 \%$ had a migraine, and $64 \%$ had a stroke. The neuroimaging revealed leukoencephalopathy was present in $80 \%$ of patients, temporal white matter disorder in $64 \%$, periventricular white matter disorder in $80 \%$, and hemorrhage in none of the patients 


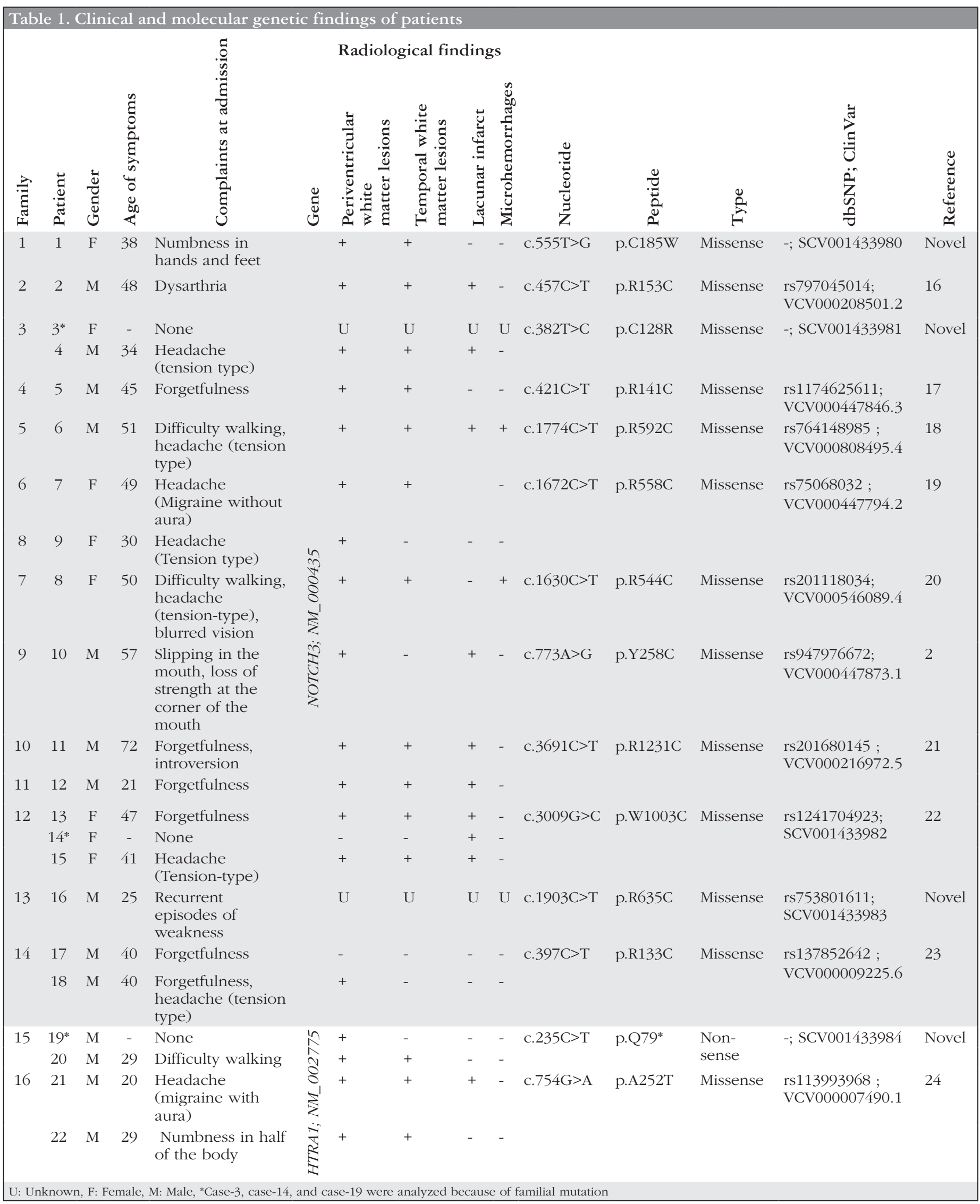




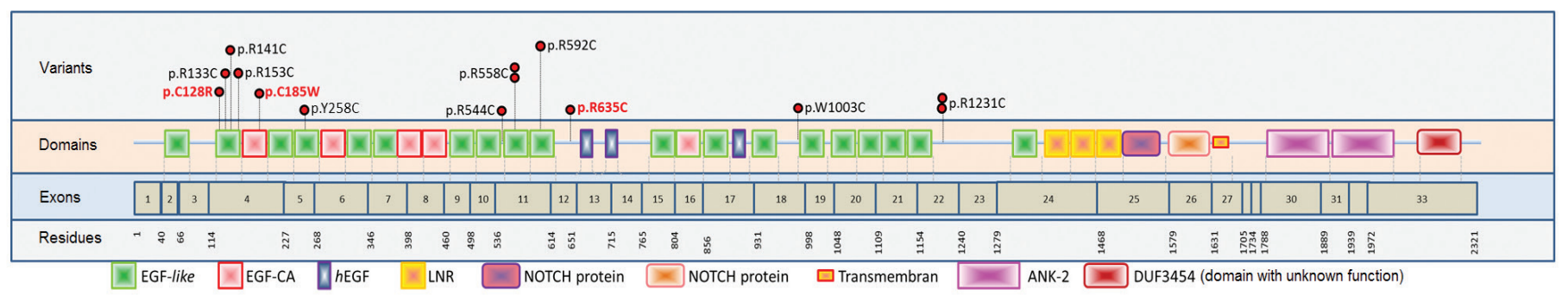

Figure 1. The NOTCH3 gene structure, domains encoded by the exons, and variants detected in patients. Variants reported for the first time in this study were written in red. The diagram of the domain and specific regions of the NOTCH3 peptide (Q9UM47) was drawn with information from the Pfam database (16). Seventeen heterodimeric epidermal growth factor (EGF)-like domains containing six cysteines that form three separate disulfide bonds in the N'-section extending out of the cell, with five EGF-calcium binding (epidermal growth factor- domains with calcium-binding properties, EGF-CA) and 3 human EGF-like (hEGF-like) within them. Other specific regions of the peptide are three LNR (Lin12/Notch related) domains, each contains approximately 35 amino acid Notch related motif, two different NOTCH protein domains, one trans-membrane domain and two ankyrin repeats (Ank-2) domain in the intracellular portion consist of 33 amino acids

(20). Our study revealed that in 18 patients from 14 families, the age of disease onset was compatible with the literature, whereas complaints of headache were present in $42 \%$, headache with migraine features was behind the literature with a rate of $11 \%$. This situation is associated with the inability of patients to clearly express their past headache characteristics due to concomitant cognitive impairment and stroke. Of our patients, $42 \%$ presented with dysarthria, weakness, difficulty in walking, and paresthesia suggestive of stroke, $46 \%$ had a stroke, with a rate close to the literature. Cognitive disorder as a presenting complaint was behind the literature with a rate of $32 \%$ in our patient group, and a history of psychiatric disorder was close to the literature with a rate of $32 \%$. Patients with CADASIL starting with psychiatric complaints were reported in the literature; however, none of our patients were diagnosed with CADASIL with a psychiatric onset (22). The cranial MRI examinations revealed that periventricular and temporal white matter involvements of our patients were close to the literature, and microhemorrhages were observed rarely, in line with the literature. The detection of $\mathrm{NOTCH} 3$ variants in our patients with CADASIL associated with cysteine transformations in the EGF-like domain in exons 4, 5, 11, 12, 19, and 22 of the gene was compatible with the literature $(5,26)$. A study conducted for the genotype-phenotype relationship of variants on the EGFlike domain revealed that patients with 1-6 domain variants had stroke age of at least 12 years earlier, a lower life expectancy, and a lower volume of white matter hyperintensity than those with 7-34 domains variants. In summary, pathogenic variants affecting EGF-like 1-6 domains progressed with a much more severe clinical picture (27). Pathogenic variants were located in EGF-like domains 1-6 in six of our CADASIL families, and in other EGFlike domains in 7 of them. Comparable to literature, the age of clinical onset was $34 \pm 11.85$ years in patients carrying variants in domains $1-6$, whereas $50.9 \pm 14.62$ years in others.

A retrospective study conducted in Germany on 411 patients (196 male and 215 female) from 215 families, in which the longterm follow-up events were examined, revealed that the median age for stroke was 50.7 years in men and 52.5 years in women, walking with assistance was 58.9 years in men and 62.1 years in women, becoming bedridden was 62.1 years in men and 66.5 years in women, and death was 64.6 years in men and 70.7 years in women (28). The study reported the most commonly shown pathogenic NOTCH3 variants (p.R90C, p.R110C, p.C117F, p.R133C, p.R141C, p.R153C, p.R169C, p.C174Y, and p.R182C) as significantly associated with a lower median mortality age. Among these pathogenic variants frequently observed in Germany, p.R90C and p.R141C were previously reported in patients in Turkey (16,18). Our study revealed that p.R133C (family 14; patient-17 and -18) was found in two patients from one family and p.R141C (family 4; patient-5) in another patient. Our patients with the p.R133C variant were two brothers in their 40 s who presented with forgetfulness. Patient-17 had additional complaints of atypical psychosis and patient-18 had a tensiontype headache. These patients reached the NOTCH3 genetic test results compatible with their findings at ages 53 and 52 years, respectively. Literature comparing the clinical, neuropsychological, and neuroimaging features of a total of 10 Finnish patients consisting of a male homozygous for the p.R133C variant, four females and five males carrying heterozygous variants revealed that the status of the homozygous patient was not much different from that of heterozygous patients, but on the heavy side of the clinical spectrum. Heterozygotes were more severely affected neuropsychologically (29). A large Han Chinese family, with seven patients carrying heterozygous p.R133C variant, revealed an increased T1, T2, and fluid-attenuated inversion recovery signal in the temporal lobes on the cranial MRI with clinical manifestations such as cognitive loss, dysarthria, migraine, numbness in the hands and feet, and unsteady gait at a similar rate with individuals with vascular risk factors such as hypertension, smoking, and alcohol consumption, and variant reported as low penetrance (30). The p.R133C variant found as heterozygous in patient-17 and -18 was not examined in asymptomatic siblings and other family members, thus no information was obtained regarding its penetrance. Our patient (patient-5) with the p.R141C variant presented with a complaint of forgetfulness that started at the age of 45 years, with urinary incontinence in the form of urgency. Our patient, treated for depression and insomnia that started at the age of 42 years in the center where he was followed up, was diagnosed with CADASIL at the age of 47 years. The patient carrying the 
p.R141C variant, previously reported from Turkey, presented with complaints of acute headache, numbness in the right arm, and urinary incontinence at the age of 41 years, and was diagnosed with CADASIL at the age of 44 years as a result of the genetic test performed for CADASIL compatible cranial MRI (19). The p.R90C variant reported from Turkey was shown in a 49-yearold female patient who presented with gait disturbance, speech difficulties, forgetfulness, and crying crises, and whose cranial MRI findings were evaluated in favor of CADASIL (17). This patient had two daughters who were aged 22 and 25 years, had migraines without aura, with normal neuroimaging. They were shown to carry the p.R90C variant. This study emphasized that migraine without aura is one of the early symptoms of CADASIL before MRI abnormalities.

Three distinct nucleic acid changes are reported in the EGFlike 1-6 domain of the NOTCH3 peptide, acting on codon 128; c.382T>G; p.C128G (31), c.383G > A; p.C128Y (32), c.383G>T; and p.C128F (33). Our study revealed that patient- 3 and -4 had a new nucleic acid variant change that caused cysteine alteration in the same codon and conversion of cysteine to arginine (c.382T $>C$; p.C128R), consistent with the literature. A literature reported four different pathogenic variants at codon 185 of the NOTCH3 peptide; c. 553T >C; p.C185R, c.553T > G; p.C185G, c.553T>A; p.C185S and c.554G >A; p.C185Y (30). The variant detected in patient- 1 in our study was a different nucleic acid change that similarly led to cysteine reduction and conversion of cysteine to tryptophan (c.555T>G; p.C185W).

The highest number of patients carrying the disease-associated variant as homozygous in the NOTCH3 gene was reported for p.R1231C (34). In a large family from India, the clinical and radiological findings of seven patients carrying this variant homozygously and six patients heterozygously were compared; The clinical spectrum was reported to be similar in homozygotes and heterozygous, but it was emphasized that long follow-up could not be performed to determine whether progression was rapid. Our study revealed that the p.R1231C variant was present in two patients from two different families (patient- 11 from family 10 and patient-12 from family 11). The first symptoms started with forgetfulness at the age of 72 years and motor weakness and urinary incontinence occurred as a result of a stroke at the age of 76 years in patient-11. The medical history revealed that CADASIL diagnosis was finalized at the age of 47 years in patient-12, whose complaints of confusing and forgetting the names of people she knew began at the age of 21 years. In Turkey, this variant was previously shown in a 74-year-old male patient with Alzheimer's disease (AD) who was admitted to the hospital with the complaint of forgetfulness at the age of 69 years (21). In addition, the p.R1231C variant was detected in the 46-year-old son of this patient, with a normal neurological examination. The father, clinically diagnosed with AD, was evaluated by two independent neurologists who were blind to $\mathrm{NOTCH} 3$ test results, and both experts clinically excluded CADASIL. These studies suggest that p.R1231C is a variant with low penetrance.

The p.R544C was a common CADASIL mutation $(90.3 \%)$ on the South Korean island of Jeju, with a higher frequency in Taiwanese patients (75-90.3\%) compared to all other CADASILassociated variants in general. The reported frequency was $27.6 \%$ in Korea, $23.1 \%$ in China, and $2.3 \%$ in the Netherlands $(35,36)$. Homozygous patients were reported in Taiwan, and a study comparing homozygotes with heterozygotes revealed no significant differences, which interpreted this situation as related to the environment, ethnicity, or genetic status (37). For example, the findings of Taiwanese patients were detected in more advanced ages (33.6-48.5 years vs. 54.1 years), and migraine (42-75\% vs. $2.7 \%)$ and anterior temporal white matter lesions (89\% vs. $44.8 \%$ ) were reported less frequently than the Caucasian patients. Specifically, white matter lesions in the anterior temporal lobe were $28.4 \%$ in Taiwanese patients with p.R544C mutation, and $82.8 \%$ in Taiwanese patients with other mutations in the same population, whilst cognitive impairment was identified in $48.1 \%$ and $24.2 \%$ respectively. Our study revealed that patient-8, carrying the p.R544C variant, presented with complaints of gait difficulty and blurred vision at the age of 50 years, and was diagnosed with CADASIL at the age of 57 years, with previous tensiontype headache and mild cognitive impairment. In a study in the literature, the p.R544C mutation was detected in the NOTCH3 genetic analysis performed due to diffuse leukoencephalopathy and multiple acute subcortical lacunar infarcts, which were observed in the cranial MRI in a patient with confusion, right hemiparesis, paresthesia, and dysarthria after orthopedic surgery, and the postoperative findings were attributed to CADASIL (38). The importance of brain imaging in postoperative confusion and NOTCH3 analysis in diagnosis and follow-up in case of diffuse leukoencephalopathy of unknown etiology were emphasized in patients with symptoms alleviated with hydration and antiplatelet medication. Changes of c.1903C>T (p.R635C) in exon 12 in patient-16, and change of c.3009G $>C$ (p.W1003C) in exon 19 in three siblings from family-12 (patient-13, -14, and -15) were located within region 7-34 of the EGF-like domain. These variants, like other CADASIL-associated $\mathrm{NOTCH} 3$ pathogenic variants, lead to increased cysteine within the EGF-like domain structure. Patient-16, with unreachable cranial MRI, was admitted at the age of 30 years due to recurrent episodes of weakness since the age of 25 years, with pyramidal and extrapyramidal findings. The change of p.W1003C in family-12 was first shown in a 38-yearold male patient who presented with forgetfulness, slow motor movements, urinary incontinence, and migraine attacks with aura. The same variant was detected in all his four siblings, with very mild findings in his younger siblings (23). From family-12, patient-13 presented with forgetfulness at the age of 47 years, and patient-15 presented with a tension-type headache at the age of 41 years. Patient-13 had pyramidal findings as well as cognitive impairment. Patient-14, who had the same variant in this family, was 53 years old, without complaints, but with lacunar infarcts in the cranial MRI. This shows the variability in expression of p.W1003C in our family. Our analysis, using the information shared in the HGMD database, observed that $75 \%$ of the NOTCH3 gene substitution type changes were associated with cysteine, $22 \%$ were with other missense mutations, $2 \%$ were non-sense mutations and $<1 \%$ were silent mutations. A non-conventional missense mutation (p.H243P) in the EGF-like 1-6 domain region was shown in a 37-year-old patient in Turkey whose cranial MRI findings were compatible with CADASIL (24).

In bi-allelic pathogenic HTRA1, which is similar to $\mathrm{NOTCH} 3$ pathology in terms of cranial MRI findings, high signal intensity in the periventricular deep white matter and multiple lacunar infarcts in the basal ganglia and thalamus are observed. In our patient group, prominent white matter lesions were observed 
in the periventricular and temporal regions in all three patients with HTRA1 pathology, who were symptomatic, with accessible MRI. The white matter pathology extended to the brain stem and cerebral peduncle in one of these patients.

In addition to 8 non-sense, 4 deletions, 3 silent, 2 insertion, and 1 splicing-type mutations have been described in the HTRA 1 gene, 47 different missense changes were reported so far, 6 of which were in the Kazal-2 domain, 28 in Trypsin-like, and 1 in the PDZ domain (Pfam-Q92743) (15). In our study, p.Q79*, shown in patient-19 and -20, was previously unidentified and was expected to form an early "stop" codon in protein translation and caused the absence of HTRA serine peptidase in the cell. The other change is shown in the HTRA1 gene in patient-21 and -22 was of the missense type (p.A252T), which was first described in a Japanese woman. It causes a $20-50 \%$ decrease in serine protease activity, which is unable to suppress TGF- $\beta$. Therefore, causing an increased extra A domain of fibronectin and versican in the thickened tunica intima (9). The patient's medical history was as follows: Lumbago at her teens, leukoaraiosis on brain MRI, acute stroke, gait difficulty, pseudobulbar palsy at 38 years of age pyramidal findings at 48 years old and alopecia was not reported (39).

\section{Conclusion}

The phenotypic variability associated with the NOTCH3 and HTRA1 genes makes the clinical prognosis prediction of the disease difficult; however, long-term follow-up of patients contributes to the understanding of the effects of neurologic markers specific to the variant in the gene on prognosis. Establishing special protocols is very important for patients to receive genetic counseling before and after molecular testing and to provide psychological support to families.

\section{Ethics}

Ethics Committee Approval: The study was approved by the Ethics Committee of Istanbul University, Istanbul Faculty of Medicine (date: 17.12.2015, no: 398480).

Informed Consent: Signed consent was obtained.

Peer-review: Externally and internally peer-reviewed.

\section{Authorship Contributions}

Surgical and Medical Practices: B.S., M.K., U.A., T.G., G.Y.S., Ş.A., H.G., B.B., M.E., H.H., Concept: B.S.R., F.T., Z.O.U., Design: B.S., Z.O.U., Data Collection or Processing: B.S.R., B.S., F.T., M.K., U.A., T.G., G.Y.S., Ş.A., H.G., B.B., G.T., M.E., H.H., Z.O.U., Analysis or Interpretation: B.S.R., B.S., F.T., M.K., U.A., T.G., G.Y.S., S..A., H.G., B.B., G.T., M.E., H.H., Z.O.U., Literature Search: B.S.R., B.S., F.T., Z.O.U., Writing: B.S.R., B.S., Z.O.U.

Conflict of Interest: No conflict of interest was declared by the authors.

Financial Disclosure: This study was supported by the Scientific Research Projects Unit of Istanbul University with the project TYL-2016-20217.

\section{References}

1. Carare R, Hawkes C, Jeffrey M, Kalaria R, Weller R. cerebral amyloid angiopathy, prion angiopathy, CADASIL and the spectrum of protein elimination failure angiopathies (PEFA) in neurodegenerative disease with a focus on therapy. Neuropathol Appl Neurobiol 2013;39:593-611.
2. Tournier-Lasserve E, Joutel A, Melki J, et al. Cerebral autosomal dominant arteriopathy with subcortical infarcts and leukoencephalopathy maps to chromosome 19q12. Nat Genet 1993;3:256-259.

3. Joutel A, Corpechot C, Ducros A, et al. Notch3 mutations in CADASIL, a hereditary adult-onset condition causing stroke and dementia. Nature 1996;383:707-710.

4. Penton AL, Leonard LD, Spinner NB. Notch signaling in human development and disease. Semin Cell Dev Biol 2012;23:450-457.

5. Ungaro C, Mazzei R, Conforti F, et al. CADASIL: extended polymorphisms and mutational analysis of the NOTCH3 gene. J Neurosci Res 2009;87:1162-1167.

6. Narayan S, Gorman G, Kalaria R, Ford G, Chinnery P. The minimum prevalence of CADASIL in northeast England. Neurology 2012;78:10251027.

7. Moreton F, Razvi S, Davidson R, Muir K. Changing clinical patterns and increasing prevalence in CADASIL. Acta Neurol Scand 2014;130:197-203.

8. Rutten JW, Dauwerse HG, Gravesteijn G, et al. Archetypal NOTCH3 mutations frequent in public exome: implications for CADASIL. Ann Clin Transl Neurol 2016;3:844-853.

9. Hara K, Shiga A, Fukutake T, et al. Association of HTRA1 mutations and familial ischemic cerebral small-vessel disease. N Eng J Med 2009;360:17291739.

10. Massagué J. TGF $\beta$ signalling in context. Nat Rev Mol Cell Biol 2012;13:616-630.

11. Verdura E, Herve D, Scharrer E, et al. Heterozygous HTRA1 mutations are associated with autosomal dominant cerebral small vessel disease. Brain 2015;138:2347-2358.

12. Wu X, Li C, Mao J, et al. Heterozygous HTRA1 missense mutation in CADASIL-like family disease. Braz J Med Biol Res 2018;51:e6632.

13. Fernández-Suárez XM, Schuster MK. Using the ensembl genome server to browse genomic sequence data. Curr Protoc Bioinformatics 2010; Chapter 1:Unit1.15.

14. Landrum MJ, Lee JM, Benson M, et al. ClinVar: improving access to variant interpretations and supporting evidence. Nucleic Acids Res 2018;46:D1062-D1067.

15. Stenson PD, Mort M, Ball EV, et al. The Human Gene Mutation Database: towards a comprehensive repository of inherited mutation data for medical research, genetic diagnosis and next-generation sequencing studies. Hum Genet 2017;136:665-677.

16. El-Gebali S, Mistry J, Bateman A, et al. The Pfam protein families database in 2019. Nucleic Acids Res 2019;47:D427-D432.

17. Utku U, Celik Y, Uyguner O, Yüksel Apak M, Wollnik B. CADASIL syndrome in a large Turkish kindred caused by the R90C mutation in the Notch3 receptor. Eur J Neurol 2002;9:23-28.

18. Uyguner Z, Siva A, Kayserili H, et al. The R110C mutation in Notch3 causes variable clinical features in two Turkish families with CADASIL syndrome. J Neurol Sci 2006;246:123-130.

19. Özgür B, Özgür E, Aylin Y, Oya UZ. CADASIL: Case Report. Türkiye Nöroloji Klinikleri 2014;9:118-122.

20. Ince B, Benbir G, Siva A, et al. Clinical and radiological features in CADASIL and NOTCH3-negative patients: a multicenter study from Turkey. Eur Neurol 2014;72:125-131.

21. Guerreiro RJ, Lohmann E, Kinsella E, et al. Exome sequencing reveals an unexpected genetic cause of disease: NOTCH3 mutation in a Turkish family with Alzheimer's disease. Neurobiol Aging 2012;33:1008.e17-e23.

22. Dericioglu N, Vural A, Agayeva N, et al. Cerebral autosomal dominant arteriopathy with subcortical infarcts and leukoencephalopathy (CADASIL) in two siblings with neuropsychiatric symptoms. Psychosomatics 2013;54:594-598.

23. Algahtani H, Shirah B, Alharbi SY, et al. A novel heterozygous variant in exon 19 of notch 3 in a saudi family with cerebral autosomal dominant arteriopathy with subcortical infarcts and leukoencephalopathy. J Stroke Cerebrovasc Dis 2020;29:104832.

24. Sari US, Kisabay A, Batum M, et al. Cadasil with atypical clinical symptoms, magnetic resonance imaging, and novel mutations: two case reports and a review of the literature. J Mol Neurosci 2019;68:529-538.

25. Beşpinar FU, Beşpinar LZ. Türkiye'de hane halki yapilari ve evlilik pratiklerinde ikili resim: geleneklerin yani sira değişimin yansimalari. Nüfusbilim Dergisi 2017;39:109-149. 
26. Xiromerisiou G, Marogianni C, Dadouli K, et al. Cerebral autosomal dominant arteriopathy with subcortical infarcts and leukoencephalopathy revisited: Genotype-phenotype correlations of all published cases. Neurol Genet 2020;6:e434.

27. Rutten JW, Van Eijsden BJ, Duering M, et al. The effect of NOTCH3 pathogenic variant position on CADASIL disease severity: NOTCH3 EGF 1-6 pathogenic variant are associated with a more severe phenotype and lower survival compared with EGFr 7-34 pathogenic variant. Genet Med 2019;21:676-682.

28. Opherk C, Peters N, Herzog J, Luedtke R, Dichgans M. Long-term prognosis and causes of death in CADASIL: a retrospective study in 411 patients. Brain 2004;127:2533-2539.

29. Tuominen S, Juvonen V, Amberla K, et al. Phenotype of a homozygous CADASIL patient in comparison to 9 age-matched heterozygous patients with the same R133C Notch3 mutation. Stroke 2001;32:1767-1774.

30. Tan Q-C, Zhang J-T, Cui R-T, et al. Characteristics of CADASIL in Chinese mainland patients. Neurol India 2014;62:257.

31. Coto E, Menéndez M, Navarro R, García-Castro M, Alvarez V. A new de novo Notch3 mutation causing CADASIL. Eur J Neurol 2006;13:628-631.

32. Kalimo H, Ruchoux MM, Viitanen M, Kalaria RN. CADASIL: a common form of hereditary arteriopathy causing brain infarcts and dementia. Brain Pathol 2002;12:371-384.
33. Testi S, Malerba G, Ferrarini M, et al. Mutational and haplotype map of NOTCH3 in a cohort of Italian patients with cerebral autosomal dominant arteriopathy with subcortical infarcts and leukoencephalopathy (CADASIL). J Neurol Sci 2012;319:37-41.

34. Abou Al-Shaar H, Qadi N, Al-Hamed MH, Meyer BF, Bohlega S. Phenotypic comparison of individuals with homozygous or heterozygous mutation of NOTCH3 in a large CADASIL family. J Neurol Sci 2016;367:239-243.

35. Liao Y-C, Hsiao C-T, Fuh J-L, et al. Characterization of CADASIL among the Han Chinese in Taiwan: distinct genotypic and phenotypic profiles. PloS One 2015;10:e0136501.

36. Choi JC, Song SK, Lee JS, Kang S-Y, Kang J-H. Headache among CADASIL patients with R544C mutation: prevalence, characteristics, and associations. Cephalalgia 2014;34:22-28.

37. Mukai M, Mizuta I, Ueda A, et al. A Japanese CADASIL patient with homozygous NOTCH3 p. Arg544Cys mutation confirmed pathologically. J Neurol Sci 2018;394:38-40.

38. Hsiao C-T, Chen Y-C, Liu Y-T, Soong B-W, Lee Y-C. Acute simultaneous multiple lacunar infarcts as the initial presentation of cerebral autosomal dominant arteriopathy with subcortical infarcts and leukoencephalopathy. J Chin Med Assoc 2015;78:424-426.

39. Nozaki H, Kato T, Nihonmatsu M, et al. Distinct molecular mechanisms of HTRA1 mutants in manifesting heterozygotes with CARASIL. Neurology 2016;86:1964-1974. 